\title{
THE EFFECT OF AN INSTRUCTIONAL PROGRAM BASED ON YOUTUBE ON JORDANIAN EFL STUDENTS' LISTENING
}

\author{
Asma' Mohammad Al-Ghazu Abdallah Baniabdelrahman \\ ${ }^{1}$ Research Scholar, Department of Curriculum and Methods of Instruction, Faculty of Education, Yarmouk \\ University, Jordan \\ ${ }^{2}$ Professor, Department of Curriculum and Methods of Instruction, Faculty of Education, Yarmouk University, \\ Jordan
}

\section{ARTICLE INFO}

Received: 13 December 2021

Revised: 26 February 2022

Accepted: 28 February 2022

Keywords:

Instructional Program,

Jordanian EFL Students,

Listening, YouTube

Corresponding Author:

Asma' Al-Ghazu

Email: asmaalghazu@just.edu.jo Copyright (@ 2022 by Author(s)

This work is licensed under the Creative Commons Attribution International License (CC BY 4.0). $\mathrm{http} / / /$ creativecommons.org/licenses/ by/4.0/

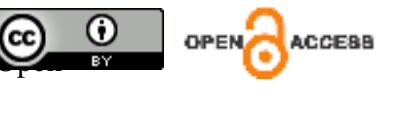

\begin{abstract}
Purpose: The study aimed to investigate the effect of using a YouTube-based instructional program on university students' listening comprehension in Jordan. Approach/Methodology/Design: The researchers followed a quasi-experimental design which consisted of one independent variable and one dependent variable. The sample included students majoring in English Language and Linguistics at Jordan University of Science and Technology (JUST), Juniors and Seniors who were distributed into two groups, a control group consisting of (46) students and an experimental group of (51) students.

Findings: The results showed that there are statistically significant differences at $(\square=0.05)$ in the post-listening test scores due to the teaching method (namely, YouTube) in favor of the experimental group.

Practical Implications: The results of this study might have practical implications for the Ministry of Education, teachers, and students. The recommendations should be applied to enhance students' performance. Technology is incorporated into the teaching/learning process, and the results of this study might give insights into the students' responses and adjustments.

Originality/value: The results of this study revealed that the YouTube-based instructional program was effective in improving the students' listening skills as compared with the conventional methodology. In this case, implementing YouTube is highly recommended and should be widely rooted in the Jordanian EFL classes as its advantages are aplenty.
\end{abstract}

\section{INTRODUCTION}

Listening is one of the most important skills that are needed in the development of other skills in any language $(\mathrm{Xu}, 2011)$. Listening comprehension is not only about hearing a spoken text, but it also involves comprehending and making sense of what is being said. Students find it challenging because they cannot translate the spoken text word-by-word (Alabsi,2020). Students find it difficult to understand the listening material and what is being discussed by the teacher without learning aids. Communication will not be easy and smooth without focusing on listening which is considered the basis for good speaking skills (Dheghu, Mata, Rita, 2020). Technology has occupied a very important role in most aspects of our lives especially education where the teaching-learning process is the most important goal and target(Sejidu,2017). The traditional classrooms being compared to a world that is dominated 
by digital technological equipment and applications such as smartphones, iPads, and YouTube videos are no longer the favored option for all students. To cope with this rapid change in educational technology, educators and experts in the EFL teaching-learning process need to come up with new strategies at all educational levels (Saed, Haider, A-Salman \& Hussein, 2021).

The Internet has provided teachers and students with rich sources of video materials such as Facebook, Twitter and YouTube (Al-Faki \& Alharthy, 2014). Benefitting from Internet-based technology such as YouTube videos to improve students' comprehending and producing abilities has become a necessity(Sejidu, 2017). Although using the Internet has been expected to play a significant role in the teaching and learning process, there are still obstacles such as the condition of schools, lack of computers and lack of training (Baniabdelrahman, Bataineh, \&Bataineh, 2007).

When students watch video materials, it activates verbal and non-verbal parts together which may enable students to connect the body language they watch in videos to the spoken words they find difficult which will eventually lead to listening comprehension (Lin \& Duy, 2014). Videos may also encourage interactions and discussions among students inside and outside the language classroom because videos provide authentic contexts that include both verbal and non-verbal gestures that may be used by students to reach a suitable input (Shyamlee \&Phil, 2012).

YouTube is one of the most popular video-sharing websites that was established in 2005. Every month, about a billion hours of video content are streamed on YouTube with billions of views and more than two billion logged-in users (YouTube.com,2021). With the Covid19 pandemic all the challenges related to it, the whole educational system has been forced to cope with this global shift in education towards online learning. Technology is now a necessity not only in Jordan but in the whole world due to the Covid19 pandemic and this may direct the educational system towards blended teaching (Saed, Haidar, Al-Salman, Hussein,2021).

Since YouTube makes the learning process more enjoyable for students because they are exposed to authentic videos that help students understand and experience new cultures, students' attitudes towards integrating it in the classroom have revealed positive points of view. YouTube videos easy accessibility either on smartphones or laptops have made it easy for students to watch the videos inside and outside the classroom and thus this has increased motivation towards improving their listening skills(Sari, 2018).

Despite all the positive aspects for integrating technological tools inside the language classroom to improve the student's communication skills in general and listening in particular, the Jordanian classroom still faces obstacles even though Jordan is making efforts to implement measures that will improve the quality of the teaching and learning process (Baniabdelrahman, Bataineh \& Bataineh,2007).

During one of the researcher's work as a Full-Time Lecturer at the Department of English Language and Linguistics at Jordan University of Science and Technology, she noticed that the challenging skill for EFL students is listening which usually results in a weakness in this important skill. This study is an attempt to integrate technology (namely, YouTube) as a supplement to the conventional methods to improve students' listening skills in the Jordanian EFL classroom. This study investigates the effect of using YouTube videos on Jordanian students' listening skills through answering the following question: Are there any statistically significant differences $(\mathrm{a}=0.05)$ between the experimental and control groups students' scores 
in the post-test in listening that are attributed to the teaching methods, the YouTube vs. the conventional?

By implementing this study, the researchers hope to understand the effect of integrating Web2.0; namely YouTube, in Jordanian listening classrooms. A huge number of young people get used to the rapid technological developments easily and quickly, so if this study shows a significant difference, the results may be encouraging to researchers who attempt to integrate YouTube application in Jordanian universities to enhance students' level in listening.

\section{LITERATURE REVIEW}

Some problems face students and teachers while learning or teaching oral/aural skills. Teachers' selection of materials is not studied or planned thoroughly (Baniabdelrahman, Bataineh, \&Bataineh, 2007). The main reason for the two skills is not passing courses but preparing students to interact in social situations. What students hear inside the language classroom is far away from what is needed in real life because most listening/speaking materials judge students' memory rather than their understanding (Huang, 2009).

Listening should be considered an active process instead of a passive process which is because when students listen, this means that they try to interpret the message delivered and the challenge becomes trying to comprehend it because students mostly skip the part related to comprehension due to its difficulty. Students face challenges such as the rate of the speech, the different accents and the structure of the spoken language. For students to attempt to handle speaking short conversations, they must emphasize on trying to be competent listeners which require both interpretation and comprehension and once listening is achieved then as a result speaking is achieved too $(\mathrm{Xu}, 2011)$.

Multimedia technology and the Internet play a very crucial role in improving language learning through improving listening by changing classroom environments which today can integrate video materials to assist the traditional teaching plan but teachers must be very careful because technology is double-faced which can work positively when used with careful planning and can also work negatively if implemented improperly (Shyamlee \& Phil, 2012). Using multimedia technology to enhance students' listening abilities can be effective through encountering and learning a language in real-life situations and it is believed that if listening comprehension improves, other language skills, speaking, reading, and writing will improve as well (Sejidu, 2017).

With the huge number of videos worldwide, teachers face challenges before finding the suitable content to teach inside the language classroom because the choice must be based on several standards such as the purpose and outcomes that teachers desire to achieve and also the content of the selected videos must suit the teaching/learning environment besides relating to everyday contexts, plus taking into consideration students' gender, grade level, age and religious beliefs (Berk, 2009). A creative teacher uses the appropriate multimedia tool which is designed to assist classroom traditional materials through focusing on the elements of authenticity and flexibility and teachers must take into account that the main reason behind using audio-visual videos is improving listening and speaking through providing more discussions and interactions so that students understand language in engaging in real-life contexts (Sejidu, 2017).

Integrating and using technological innovations as an instructional tool has been a debatable issue concerning its advantages and disadvantages. Students and with the growth of 
technology find that enhancing listening abilities become easier because technological tools allow them to access the suitable videos needed without facing major difficulties because of the availability of authentic materials worldwide and students can listen to and watch a large number of videos to build their listening abilities at the time and place of their choice and as a result move a step forward to being independent learners. The Internet also makes teachers and students encourage the idea of integrating technology inside the language classroom to improve listening provided that schools provide the needed technological equipment (Bohloulzadeh\& Rahmatollahi, 2017).

YouTube can be used inside and outside the language classroom to improve listening. YouTube videos can provide real-life situations and can direct students towards self-study learning. The limitless source of worldwide videos provides teachers and students with a boundless number of all types of clips that can be used as a supplement for the classroom materials so that teachers can examine students listening skills regarding voice intonations, stress and correct pronunciation. Encouraging student-centered learning with the guidance of teachers provides students with opportunities to browse YouTube to select the type of videos they prefer to watch at the time they find suitable as a back-up to the neglected materials inside the language classroom (Watkins \& Wilkins, 2011).

Nowadays and with the availability of the Internet, integrating technology such as podcasts in the educational process provides students and teachers with alternatives and opportunities that enable students to control their learning progress. Developing listening faces challenges and needs a great deal of practice and involvement in real-life contexts with native speakers but the use of technology motivates students to be engaged in listening classroom discussions. Audio-visual videos allow students to follow the learning styles that are suitable for them. When restrictions are removed, students find learning interesting and as a result listen to various topics that will enrich them with new ideas to discuss and that facilitate reaching their educational goals and improves their listening (Ramli, 2017).

Teachers and students can upload, watch and discuss all types of videos such as movies, songs, and educational clips. In addition, YouTube can be a very interesting tool, and it can be very helpful in students' progress regarding listening and speaking. Watching native speakers talk contributes to improving pronunciation. Besides, it enables interacting and sharing ideas. Teachers face challenges such as the availability of the needed technological equipment and the accessibility of the Internet. The possibility of teachers' ability to download and save YouTube videos to avoid the challenge of Internet interruptions is used as a solution even though it deprives students of benefitting from the related videos and the comments which are considered as a very important element of the YouTube listening classrooms because the benefits that can be acquired from the downloaded videos are countless (Silviyanti, 2017).

YouTube videos in classrooms provide both students and teachers with fast and entertaining instructional materials worldwide. YouTube videos are considered an effective learning medium that students find enjoyable and thus students have significant opportunities for engaging in the learning process in a meaningful way (Saed, Haider, AL-Salman, Hussein,2021).

\section{Empirical Research}

Genc Ilter (2009) aimed to find out how technology could be used to increase students' motivation in EFL classrooms. A questionnaire was administered to a group of students at 
Akdeniz University in the 2007-2008 academic year. The study showed that technology was a dynamic and challenging factor inside the EFL classroom.

Jou (2010) aimed to point out the link between listening strategies used by technological university students in exams and listening skills. The participants were 239 university students from a technological university in southern Taiwan. The students were selected from different levels. They were chosen randomly from four colleges both males and females. Students were given a test which is adapted from General English Proficiency Test. The test was designed to examine the students' knowledge of vocabulary, idioms, and grammar. He concluded that students still need a lot of training and teaching.

Rocio (2012) investigated the point of teaching listening alongside grammar to improve the level of Spanish students depending on selected activities. The participants were 150 male/female first-year students of low English level who were asked about their point of view about listening. The time spent inside classes on teaching and practicing both skills were observed and the teacher was interviewed to know the way of organizing the lesson, the type of exercises used in classes, and the problems encountering both students and teachers.

Lin and Duy (2014) investigated whether video internet materials affected international students' listening comprehension positively and also examined their attitudes towards inserting videos inside language classrooms. The students were divided into an experimental and a control group and the results showed that the experimental group students who studied using video internet materials and narrations showed a significant improvement over the control group students who studied narrations only. Rahimi and Soleymani (2015) examined the effect of mobile phones on students' listening anxiety and progress. The experimental group did their listening activities using podcasts on their mobile phones while the control group used desktop computers to do their listening activities. The results showed a clear difference in the two groups' listening performance in favor of the experimental over the control group due to a decrease in students' anxiety which is related to using mobile phones.

Metruk (2018) investigated the possible effects of authentic English videos with subtitles and without subtitles on listening and reading skills. Thirty Slovak university EFL students were divided into three groups according to what they preferred to watch i.e. An English subtitle group, a Slovak subtitle group, and a no subtitle group. The results showed that the use of L1 and L2 subtitles had no obvious effect when it comes to the connection between watching authentic English videos with or without subtitles and the improvement of the listening comprehension but on the other hand showed a more beneficial effect on their reading.

Dheghu, Mata, Rita (2020) investigated the effects of using audio-visual aids on students' listening skills. Second-grade students of State Polytechnic in Kupang were the participants of the study. The results showed that audio-visual aids can improve students' activity and learning achievement. Qomariyah, Permana, Hidayatullah(2021) investigated the effect of applying YouTube videos on the students' listening comprehension. This study is a quasiexperimental with non-equivalent control group design. The results showed that the students' listening comprehension improved by using YouTube videos and the results also showed that the students' performance in listening comprehension improved positively.

\section{METHODOLOGY AND PROCEDURES}

\section{Design and Variables of the Study}

The current research study addresses one question, mainly focusing on the effectiveness of integrating YouTube as a teaching method to develop EFL students' listening 
comprehension. The researchers followed a quasi-experimental design which consisted of one independent variable and one dependent variable; the dependent variable is the participants' scores on the listening post-test. While the independent variable is the teaching method with which the participants were taught using YouTube Vs the conventional method.

\section{Participants of the Study}

Two sections of students majoring in English Language and Linguistics at Jordan University of Science and Technology (JUST), Juniors and Seniors were distributed into two groups, a control group consisting of (46) students and an experimental group of (51) students. These two groups participated in this study which was conducted in the first semester of the academic year 2020/2021 and lasted for eight weeks. The two groups were administered to a pre-test, which showed equivalence in the results. The control group under the study was taught conventionally while the experimental group was taught through the proposed instructional program.

\section{Instrument of the Study}

Based on Bloom's taxonomy, a table of the specification was created to form a pre-post/ test to examine the students' performance in listening. Twenty-five questions were created to focus on the following listening sub-skills: Listening for gist i.e. finding main and supporting details and guessing meaning i.e. knowing the idiomatic meaning. The pre-post /test sorted out the equivalence between groups established in the study and the degree of change in students' listening performance was measured as a result of the treatment. The pre-test was administered at the beginning of the semester.

\section{Validity and Reliability of the Instrument}

A validation jury of eight English professors and instructors were consulted to give their remarks and suggest any modifications to the Pre-Post/test. The jury's suggestions and comments were taken into consideration in modifying the test before its application. To assure the validity of the instrument, a test-re-test was administered to a pilot group of 20 students from Jordan University of Science and Technology who were not included in the sample of the study. The result was found to be 0.93 , which was acceptable.

\section{RESULTS AND DISCUSSION}

To answer the question of the study, that is: Are there any statistically significant differences $(a=0.05)$ between the experimental and control groups students' scores in the post-test in listening that are attributed to the teaching methods, the YouTube vs. the conventional? The researcher conducted the test and concluded the following results: Means and standard deviations and estimated marginal means of University students' scores in listening that are attributed to the teaching tool (namely, YouTube) vs. the conventional are shown in the table below (Table 1).

Table 1: Means, Standard Deviations and Estimated Marginal Means University Students' Scores in Post Listening Test Attributed to Teaching Method (Namely, YouTube) vs. the Conventional

\begin{tabular}{lllll}
\hline Method & Mean & Std. Deviation & $\begin{array}{l}\text { Estimated } \\
\text { Marginal } \\
\text { Means }\end{array}$ & $\mathrm{N}$ \\
\hline Experimental (namely, & 20.63 & 2.953 & 20.476 & 51 \\
\hline
\end{tabular}




\begin{tabular}{lllll}
\hline YouTube) & & & & \\
Control (conventional) & 14.84 & 3.649 & 15.016 & 45 \\
Total & 17.92 & 4.379 & 17.746 & 96 \\
\hline
\end{tabular}

Source: Authors

Table 1 shows a slight variance in the means of the post-listening test scores attributed to the teaching method (namely, YouTube) vs. the conventional, to find out whether there are statistically significant differences in these means, one way ANCOVA was conducted and the results are shown in Table 2.

Table 2: One Way ANOVA Results of Post Listening Test Scores Related to Teaching Method

\begin{tabular}{|c|c|c|c|c|c|}
\hline Source & $\begin{array}{l}\text { Sum } \\
\text { Squares }\end{array}$ & $\mathrm{df}$ & Mean Square & $\mathrm{F}$ & Sig. \\
\hline Pre test (covariate) & 235.180 & 1 & 235.180 & 27.804 & .000 \\
\hline Method & 705.285 & 1 & 705.285 & 83.380 & .000 \\
\hline Error & 786.653 & 93 & 8.459 & & \\
\hline Corrected Total & 1821.333 & 95 & & & \\
\hline
\end{tabular}

Table 2 shows that there are statistically significant differences at $(\alpha=0.05)$ in the postlistening test scores due to the teaching method (namely, YouTube) in favor of the experimental group. Means and standard deviations and estimated marginal means of (subskills) in listening that are attributed to the teaching method (namely, YouTube) vs. the conventional are shown in the table below.

Table 3: Means, Standard Deviations and Estimated Marginal Means of (Sub Skills) Attributed to Teaching Method (Namely, YouTube) vs. the Conventional

\begin{tabular}{llllll}
\hline & GROUP & Mean & $\begin{array}{l}\text { Std. } \\
\text { Deviation }\end{array}$ & $\begin{array}{l}\text { Estimated } \\
\text { Marginal } \\
\text { Means }\end{array}$ & $\mathrm{N}$ \\
\hline Main ideas & experimental & 10.24 & 1.692 & 10.122 & 51 \\
post & control & 8.20 & 2.149 & 8.329 & 45 \\
& Total & 9.28 & 2.165 & 9.225 & 96 \\
Guessing the & experimental & 10.39 & 1.710 & 10.315 & 51 \\
meaning post & control & 6.64 & 2.155 & 6.732 & 45 \\
& Total & 8.64 & 2.688 & 8.523 & 96 \\
\hline
\end{tabular}

Source: Authors

Table 3 shows a slight variance in the means of (sub-skills) attributed to the teaching method (namely, YouTube) vs. the conventional, to find out whether there are statistically significant differences in these means, one way MANCOVA was conducted and the results are shown in Table 4.

Table 4: One Way MANOCVA Results of (Sub Skills) Scores Related to Teaching Method

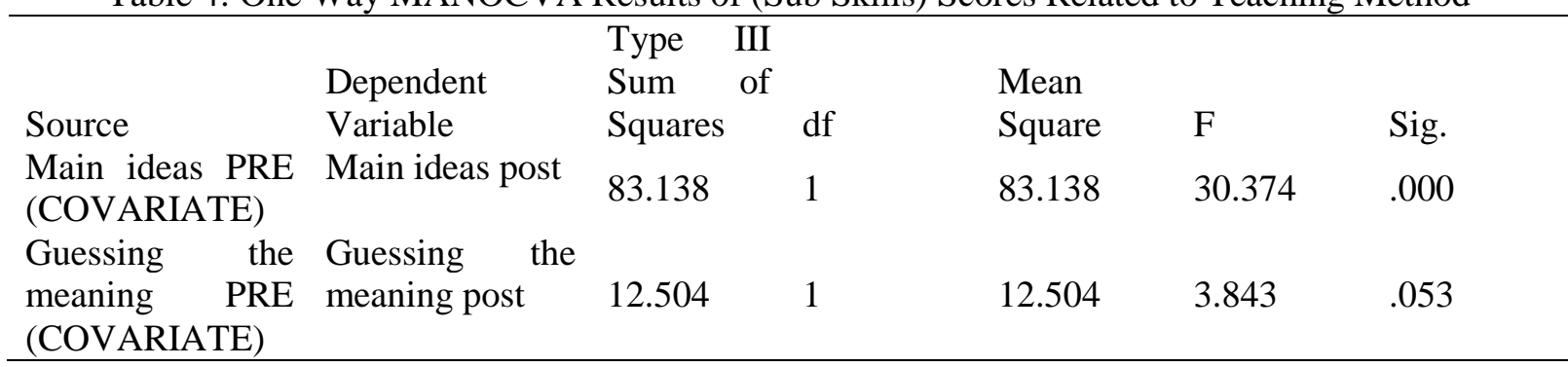




\begin{tabular}{|c|c|c|c|c|c|c|}
\hline GROUP & Main ideas post & 75.762 & 1 & 75.762 & 27.679 & .000 \\
\hline $\begin{array}{l}\text { Hotelling's } \\
\text { Trace }=1.052 \\
\mathrm{P}=0.000\end{array}$ & $\begin{array}{l}\text { Guessing the } \\
\text { meaning post }\end{array}$ & 302.490 & 1 & 302.490 & 92.957 & .000 \\
\hline Error & Main ideas post & 251.817 & 92 & 2.737 & & \\
\hline \multirow{3}{*}{ Corrected Total } & $\begin{array}{l}\text { Guessing the } \\
\text { meaning post }\end{array}$ & 299.377 & 92 & 3.254 & & \\
\hline & Main ideas post & 445.406 & 95 & & & \\
\hline & $\begin{array}{l}\text { Guessing the } \\
\text { meaning post }\end{array}$ & 686.240 & 95 & & & \\
\hline
\end{tabular}

Source: Authors

Table 4 shows that there are statistically significant differences at $(\alpha=0.05)$ in both (subskills) due to the teaching method(namely, YouTube) in favor of the experimental group.

\section{Discussion of the Results of the Research's Question}

The first question of the study seeks statistically significant differences among Jordanian university students' listening skills attributed to the teaching method (viz. YouTube). The statistical analysis of the data revealed that there was a significant difference at $(\mathrm{a}=0.05)$ between the mean scores of the students of the control and experimental groups on their listening post-test in favor of the experimental group. Hence, the improvement of the students' listening skills in the post-test can be attributed to the integration of YouTube.

The observed improvement in students' listening skills could be ascribed to several factors. Firstly, YouTube videos increase the students' motivation to learn which might be one of the significant factors that contributed to the improvement of the students' listening skills. This might be due to students' watching YouTube videos that they find enjoyable because the topics are related to real-life issues that are presented by native speakers. The nature of topics presented in the YouTube videos might be the reason for motivating students to learn because of its inspirational and valuable messages that are related to real social life issues that students need in the real world. This is consistent with Kurniawan (2016), Saed, Haider, AlSalman, and Hussein (2021), Nofrika (2019); who affirmed the unquestionable value of using YouTube in the EFL classroom where students get to be eager and keen to watch videos by native speakers.

Another possible factor is that YouTube videos enable students to listen and watch at the same time. Students are able to see the speakers' gestures and facial expressions which can enhance listening skills. The non-verbal gestures might be very helpful for students because linking what you listen to with the body language enables them to see the language used and not just listen to it and this might help them understand words or phrases from context as a whole and can give them a better insight into the topics through visual support. This is consistent with Ningityas, Suryati, and Ariani (2020) and Qomariyah, Permana, and Hidayatullah (2021) who asserted the significance of non-verbal gestures as a helpful means besides the verbal context for students listening improvement.

Besides, the accessibility and flexibility of YouTube could have played a role in improving students' listening as it is easy to watch on their smartphones or personal computers whenever they want. The steps to access any YouTube video are also easy and simple provided that students have internet connections. Students are also able to repeat videos more than one time at a pace that is suitable for them. The quality of the voice and picture for videos can be modified to reach the clarity needed. This is consistent with Nofrika(2019) who 
affirmed that the improvement of students' listening skills can be attributed to the features that YouTube videos as a teaching tool acquire.

YouTube provides students with content that illustrates concepts and principles that benefit them in the real world in all the fields of life such as the youth's role in society, bullying, family relationships, etc. Such videos encourage students to participate and share their points of view in classroom discussions.

Although designing and organizing suitable material for students is very challenging for the teacher, preparing it in advance makes students feel that the class is under control and it is not time-consuming. Another possible reason can be related to the feedback provided by the teacher inside the classroom. The appropriate and encouraging feedback that students receive from the teacher builds self-confidence and lessens anxiety among students and thus increases their motivation to participate without fearing being judged by their peers. This is consistent with Pratama, Arifin, and Widyaningsih (2020) who emphasized the significant role of the teacher inside the classroom through good planning and well-management for the material with taking into consideration students' needs.

\section{CONCLUSION AND SUGGESTION}

The results of the question of this study revealed that the YouTube-based instructional program was effective in improving the students' listening skills as compared with the conventional methodology. This study presented evidence in the subskills of listening skills. This improvement could be attributed to some factors. First of all, the integration of YouTube inside the classroom does not require any complicated facilities. Also, enhancing the students' intrinsic motivation through addressing their needs, preferences, and proficiency levels. Finally, incorporating the subskills of listening through providing the target students with ample meaningful exposure to the target language accompanied with adequate practice. The researchers of this study recommend that teacher's role should be changed from a dominator into a provider, assistant, facilitator, and consultant who is able to construct a variety of effective strategies and methods with some enjoyable real-life activities. In this case, implementing YouTube is highly recommended and should be widely rooted in the Jordanian EFL classes as its advantages are aplenty.

\section{CONFLICT OF INTEREST}

There are no conflicts of interest with this paper.

\section{FUNDING}

The costs of conducting the study and publishing this article are of the authors.

\section{REFERENCES}

Alabsi, T. (2020). Effects of adding subtitles to video via apps on developing EFL students' listening comprehension. Theory and Practice in Language Studies, 10(10), 11911199. http://dx.doi.org/10.17507/tpls.1010.02

Baniabdelrahman, A., Bataineh, R., \& Bataineh, R. (2007). An Exploratory Study of Jordanian EFL Students' Perceptions of the Internet. Teaching English with Technology, 7(3). https://bibliotekanauki.pl/articles/569283

Berk, R. A. (2009). Multimedia teaching with video clips: TV, movies, YouTube, and mtvU 
in the college classroom. International Journal of Technology in Teaching \& Learning, 5(1). 1213-1223 https://doi.org/10.4236/ce.2014.513137

Dheghu, Y. P., \& Rosdiana Mata, P. R. (2021, April). Improving Students' Listening Skill Using Audio Visual Aids. In International Conference on Applied Science and Technology on Social Science (ICAST-SS 2020) (pp. 411-413). Atlantis Press.

Alfaki, I. M. \& AlHarthy, K (2014). Towards a digital world: Using Social Networks to Promote Learner's Language. 4(10), 105-114.

Genc Ilter, B. (2009). Effect of technology on motivation in EFL classrooms. Online Submission, 10(4), 86-100. http://redi.ufasta.edu.ar:8080/xmlui/handle/123456789/875

Huang, H. (2009) How to teach Aural English More Effectively. English Language Teaching , 2(3),213-218. https://doi.org/10.5539/elt.v2n3p213

Jou , Y. (2010) A Study of English Listening Strategies Applied by Technological University Students. Journal of Toko University,152. http://dx.doi.org/10.46827/ejel.v6i3.3653

Lin, L. F., \& Duy, L. D. (2014). The impacts of the video-based Internet materials on international students' listening comprehension. International Journal on Studies in English Language and Literature, 2(8), 106-115.

Metruk, R. (2018). The Effects of Watching Authentic English Videos with and without Subtitles on Listening and Reading Skills of EFL Learners. EURASIA Journal of Mathematics, Science and Technology Education, 14(6), 2545-2553. https://doi.org/10.29333/ejmste/90088

NamazianDost, I., Bohloulzadeh, G., \& Rahmatollahi, R. (2017). The Effects of Using Podcast on Listening Comprehension among Iranian Pre-intermediate EFL Learners. International Journal of Applied Linguistics and English Literature, 6(6), 57-70. http://dx.doi.org/10.7575/aiac.ijalel.v.6n.6p.57

Ningtiyas, W. A., Suryati, N., \& Ariani, N. (2021). Students' Intensity in Watching English Videos on YouTube and their Listening Skill. Journal of English Language, Literature, and Teaching, 4(2), 52-57.

Nofrika, I. (2019). EFL Students' Voices: The Role of YouTube in Developing English Competences. Journal of Foreign Language Teaching and Learning, 4(1), 56-73. https://doi.org/1010.18196/ftl.4138

Pratama, S. H. H., Arifin, R. A., \& Widianingsih, A. W. S. (2020). The Use of YouTube as a Learning Tool in Teaching Listening Skill. International Journal of Global Operations Research, 1(3), 123-129.

Qomariyah, S. S. A., Permana, D., \& Hidayatullah, H. (2021). The Effect of YouTube Video on Students' Listening Comprehension Performance. Journal of English Language Teaching, 8(1), 67-73. https://doi.org/10.33394/jo-elt.v8i1.3837

Rahimi, M., \& Soleymani, E. (2015). The impact of mobile learning on listening anxiety and listening comprehension. English Language Teaching, 8(10), 152-161. http://dx.doi.org/10.5539/elt.v8n10p152

Ramli, A. (2017). The Use of Podcast to Improve Students' Listening and Speaking Skills for EFL Learners. In International Conference on English Language Teaching (ICONELT 2017). Atlantis Press.

Saed, H. A., Haider, A. S., Al-Salman, S., \& Hussein, R. F. (2021). The use of YouTube in developing the speaking skills of Jordanian EFL university students. Heliyon, 7(7), e07543. https://doi.org/10.1016/j.heliyon.2021.e07543

Sejdiu, S. (2017). Are listening skills best enhanced through the use of multimedia technology. Digital Education https://doi.org/10.1344/der.2017.32.60-72

Shyamlee, S. D., \& Phil, M. (2012). Use of technology in English language teaching and 
learning: An analysis. In International Conference on Language, Medias and Culture(Vol. 33, pp.150-156).

Silviyanti, T. M. (2014). Looking into EFL students' perceptions in listening by using English movie videos on YouTube. Studies in English language and Education, 1(1), 42-58. http://doi.org/10.24815/siele.vlil.1119

Watkins, J., \& Wilkins, M. (2011). Using YouTube in the EFL classroom. Language Education in in Asia, 2(1),113-119. https://doi.org/10.5746/LEiA/11/V2/I1/A09/Watkins_Wilkins

$\mathrm{Xu}, \mathrm{F}$. (2011). The Priority of Listening Comprehension over Speaking in the Language Acquisition Process. International Education Studies, 4(1), 161-165. https://doi.org/10.5539/ies.v4n1p161 